\title{
ANALISIS PENGARUH PROFITABILITAS, SOLVABILITAS, AKTIVITAS, DAN RISIKO INVESTASI TERHADAP RETURN SAHAM PADA PERUSAHAAN SEKTOR OTOMOTIF DAN KOMPONEN
}

Oleh:

Riska Fethy Liana

\author{
riskafliana@gmail.com
}

Abstrak

Penelitian ini bertujuan untuk menguji adanya pengaruh kinerja keuangan (profitabilitas, solvabilitas, aktivitas) dan risiko investasi terhadap return saham perusahaan. Profitabilitas diukur dengan menggunajan Net Profit Margin (NPM). Solvabilitas diukur dengan menggunakan Debt to Equity ratio (DER). Rasio Aktivitas diukur dengan menggunakan Total Asset Turnover (TATO). Risiko investasi diukur dengan menggunakan standar deviasi. Penelitian ini menggunkana pendekatan kuantitatif dengan metode regresi berganda. Penelitian ini menggunakan sampel berupa perusahaan-perusahaan sektor otomotif dan komponennya yang listing di Bursa Efek Indonesia periode 2011-2015. Dengan total sampel yang digunakan adalah 12 perusahaan. Hasil penelitian menunjukkan bahwa secara simultan rasio profitabilitas (net profit margin), solvabilitas (debt to equity), aktivitas (total asset turnover), dan risiko investasi berpengaruh secara signifikan terhadap return saham sebesar $45,7 \%$. Sedangkan secara parsial hanya net profit margin dan risiko investasi saja yang berpengaruh dan signifikan terhadap return saham.
\end{abstract}

Kata kunci: Profitabilitas, Solvabilitas, Aktivitas, Risiko Investasi, dan Return Saham.

\begin{abstract}
The purpose of this study is to impact of financial performance which measured by profitability, solvability, activity, and investment risk toward the company's stock return. Profitability is measured by net profit margin (NPM). Solvability is measured by debt to equity ratio (DER). Activity is measured by total asset turnover (TATO). Investment risk is measured by deviation standard. This study uses quantitative approach with multiple regression method. This study uses sample of The Otomotive and Component Company which listed in Indonesia Stock Exchange period 2011-2015. The total of the sample which used in this study is 12 companies. Result show that simultant profitability ratio (NPM), solvability ratio (DER), activity ratio (TATO), and investment risk of significantly influence on stock return shares of 45,7. While partial only variable net profit margin and investment risk significantly influence toward stock return.
\end{abstract}

Keyword: profitability, solvability, activity, investment risk, stock return. 


\section{PENDAHULUAN}

Industri otomotif menjadi salah satu industri yang diunggulkan di Indonesia. Industri ini juga merupakan salah satu sektor ekonomi yang paling penting di dunia dalam hal pendapatan. Makin banyaknya kuantitas perusahaan otomotif merupakan salah satu bukti, bahwa industri otomotif telah banyak menarik perhatian banyak pihak. Indonesia memiliki perkembangan yang cukup menakjubkan pada dunia otomotif. Tidak hanya sekedar pernyataan belaka namun hal ini juga didukung oleh peneliti yang melakukan analisa terhadap perkembangan otomotif yang ada di Indonesia. Salah satunya adalah penelitian yang dilakukan oleh Vijay Rao, Automotive and Transportation Practice Frost \& Sullivan, yang menyatakan bahwa Indonesia merupakan salah satu perkembangan otomotif terbesar di ASEAN setelah Thailand. Dalam penelitian ini diprediksi bahwa Indonesia akan menjadi pasar Otomotif terbesar di ASEAN pada tahun 2019 dengan total kendaraan mencapai 2,3 juta.

Tahun 2013, ekspor produk otomotif secara keseluruhan nilainya tercatat mencapai US\$ 4,6 miliar. Angka produksi dan penjualan kendaraan bermotor tentunya menjadi cerminan potensi pasar suku cadang, aksesoris dan perlengkapan mobil dan motor. Dari total nilai tersebut, komponen otomotif yang tergolong dalam kelompok (HS 8708) - berupa komponen dan aksesoris kendaraan bermotor-tahun 2013 tercatat US\$ 1,42 milyar, berkontribusi sebesar 31,04\% dari total ekspor produk otomotif.

Berdasarkan sumber Kementerian Perindustrian tahun 2014, sebanyak 50 industri komponen otomotif berasal dari Jepang, Thailand, Malaysia dan Taiwan berencana membangun pabrik di Tanah Air. Merujuk pada realisasi investasi pabrikan komponen tahun lalu sebesar US\$ 2,3-2,4 milyar, alokasi anggaran yang disiapkan bagi 50 pemain baru diperkirakan mencapai US\$ 600-700 juta. Pembangunan ini akan dilakukan melalui pola perusahaan patungan membangun industri sendiri. Dengan semakin pesatnya pertumbuhan industri kendaraan bermotor dunia, maka akan mendorong pertumbuhan industri komponen kendaraan bermotor sebagai penyokong industri tersebut.

Perusahaan otomotif di Indonesia mencapai puncaknya pada tahun 2014, dimana Indonesia berhasil mengukir angka produksi kendaraan hingga 1.298.523 unit. Mengalahkan jumlah produksi kendaraan di negara ASEAN lainnya.

Namun perkembangan ini tidak berlangsung lama, pada Tahun 2015 perusahaan otomotif Indonesia mengalami penurunan dalam hal produksi maupun penjualan kendaraan. Berdasarkan data dari Gabungan Industri Kendaraan Bermotor Indonesia (Gaikindo), pada tahun 2015 jumlah unit kendaraan yang diproduksi mencapai 1.098 .780 unit. Angka ini turun jauh jika dibandingkan dengan jumlah produksi pada tahun sebelumnya. Penurunan angka ini juga diperkuat dengan adanya data dari AISI (Asosiasi Industri Motor Indonesia) yang menyatakan bahwa penjualan roda dua pada tahun 2015 mengalami penurunan 1,2 juta unit atau $15,2 \%$ dari 7,89 juta menjadi 6,69 juta unit. Sedangkan berdasarkan data Gaikindo, penjualan roda empat 2015 turun 16,1\% dari 1,21 juta unit menjadi 1,01 juta. Pada tahun 2016, tepatnya pada kuartal I terjadi penurunan sebesar 10,3\% pada penjualan roda dua, dan $5,3 \%$ pada roda empat. Hal ini merupakan imbas dari melemahnya nilai tukar mata uang rupiah terhadap dolar AS pada tahun 2015.

Walaupun industri otomotif dan komponen sempat mengalami penurunan dalam penjuallanya sebagai akibat dr nilai tukar dolar, namun industri sektor ini masih menjadi salah satu pilihan investasi yang menggiurkan bagi investor. Suatu negara membutuhkan dana investasi yang besar dalam proses pembangunan, sehingga perlu adanya usaha yang mengarah pada dana investasi yang bersumber dari dalam maupun luar negeri. Pasar modal merupakan salah satu alternatif pilihan sumber dana jangka panjang diantara berbagai alternatif lainnya bagi perusahaan. Dilihat dari perkembangannya, jumlah perusahaan yang menjual sahamnya di pasar modal semakin meningkat. Dalam kaitannya dengan investasi 
saham, investor memilih saham perusahaan yang layak untuk dipilih berdasarkan kriteria tertentu. Dan investor yang rasional akan mempertimbangkan dua hal yaitu pendapatan yang diharapkan (expected return) dan risiko (risk) yang terkandung dalam alternatif investasi yang dilakukan.

Bagi perusahaan-perusahaan go public, diharuskan menyertakan rasio keuangan yang relevan sesuai dengan Keputusan Ketua Bapepam Nomor KEP-51/PM/1996 tanggal 17 Januari 1996 (BEJ). Rasio-rasio ini dapat memberikan indikasi apakah perusahaan memiliki kas yang cukup untuk memenuhi kewajiban finansialnya, besar piutang yang cukup rasional, efisiensi manajemen persediaan, perencanaan pengeluaran investasi yang baik, dan struktur modal yang sehat sehingga tujuan memaksimumkan return pemegang saham dapat dicapai. Semakin baik kinerja keuangan perusahaan yang tercermin dari rasio-rasionya maka semakin tinggi return saham perusahaan.

Berdasarkan uraian yang telah dikemukakan di atas, dan melihat hasil beberapa penelitian sebelumnya, penulis tertarik untuk melakukan penelitian mengenai kinerja keuangan dan return saham pada perusahaan yang bergerak di sektor otomotif dan komponen, yang akan dituangkan dengan judul penelitian "Analisis Pengaruh Profitabilitas, Solvabilitas, Aktivitas, dan Risiko Investasi Terhadap Return Saham pada Perusahaan Sektor Otomotif dan Komponen yang Terdaftar pada Bursa Efek Indonesia Periode 2011-2015"

\section{KAJIAN PUSTAKA DAN PENGEMBANGAN HIPOTESIS}

Menurut Agnes Sawir dalam bukunya Kinerja Keuangan dan Perencanaan Keuangan (2005:1) mendefinisikan kinerja keuangan sebagai suatu kondisi yang mencerminkan keadaan keuangan suatu perusahaan berdasarkan sasaran, standar, dan kinerja yang telah ditetapkan.

Untuk dapat mengukur kinerja keuangan suatu perusahaan, biasanya melibatkan rasiorasio keuangan. Menurut Sofyan Syafri (2008:297) rasio keuangan adalah angka yang diperoleh dari hasil perbandingan dari satu pos laporan keuangan dengan pos lainnya yang mempunyai hubungan yang relevan dan signifikan (berarti). Rasio keuangan ini hanya menyederhanakan informasi yang menggambarkan hubungan antara pos tertentu dengan pos lainnya. Dengan analisis rasio ini perusahaan dapat menilai dan membandingkan dengan rasio lainnya sehingga kita dapat memperoleh informasi dan memberikan penilaian mengenai kinerja keuangan suatu perusahaan. Sofyan Syafri (2008:298) menjelaskan beberapa keunggulan dalam penggunaan rasio keuangan, diantanya yaitu:

1. Rasio merupakan angka-angka atau ikhtisar statistik yang lebih mudah dibaca dan ditafsirkan.

2. Merupakan pengganti yang lebih sederhana dari informasi yang disajikan laporan keuangan yang sangat rinci dan rumit.

3. Mengetahui posisi perusahaan ditengah industri lain

4. Menstandarisir size perusahaan

5. Lebih mudah memperbandingkan perusahaan dengan perusahaan lain atau melihat perkembangan perusahaan secara periodik atau 'time series'

6. Mempermudah perusahaan dalam melakukan prediksi dimasa yang akan datang.

\subsection{Rasio Profitabilitas}

Rasio profitabilitas atau sering juga disebut sebagai rasio rentabilitas merupakan rasio yang menggambarkan kemampuan perusahaan mendapatkan laba melalui semua kemampuan, dan sumber yang ada seperti kegiatan penjualan, kas, modal, jumlah karyawan, jumlah cabang, dan sebagainya. Jenis-jenis rasio profitabilitas, sebagai berikut:

\section{Net profit margin (profit margin on sales)}


2. Return on Investment (ROI)

3. Return on Equity (ROE)

4. Earning per Share (EPS)

\section{Net Profit Margin}

Net profit margin merupakan rasio keuangan yang mengukur kemampuan perusahaan dalam menghasilkan net income dari kegiatan operasionalnya. Rasio ini menunjukkan berapa besar persentase pendapatan bersih yang diperoleh dari setiap penjualan. Semakin besar rasio ini, maka semakin baik karena dianggap kemampuan perusahaan dalam mendapatkan laba cukup tinggi (Sofyan Syarief, 2008:304). Net profit margin dapat dihitung dengan menggunakan rumus berikut.

\section{NPM = Laba Bersih Total Sales}

\subsection{Rasio Solvabilitas}

Rasio solvabilitas (leverage) merupakan rasio yang digunakan untuk mengukur sejauh mana aktiva perusahaan dibiayai dari hutang. Artinya seberapa besar beban utang yang ditanggung perusahaan dibandingakan dengan aktivanya. Dalam arti luas, dapat dikatakan bahwa rasjo solvabititas ini menggambarkan kemampuan perusahaan dalam membayar kewajiban jangka panjangnya atau kewajiban-kewajibannya apabila perusahaan dilikuidasi (Sofyan Syarief, 2008:303). Terdapat beberapa jenis rasio solvabilitas, yaitu:

1. Debt asset rasio (debt ratio)

2. Debt equity ratio (DER)

3. Long term debt to equity ratio

4. Times interest earned

5. Fixed charge coverage

\section{Debt to Equity Ratio (DER)}

Debt to equity ratio menggambarkan perbandingan antara total hutang dengan total ekuitas perusahaan yang digunakan sebagai sumber pendanaan usaha. Dengan kata lain, rasio ini menggambarkan sampai sejauh mana modal pemilik dapat menutupi hutang-hutang kepada pihak luar. Untuk menghitung rasio ini, dapat dirumuskan sebagai berikut:

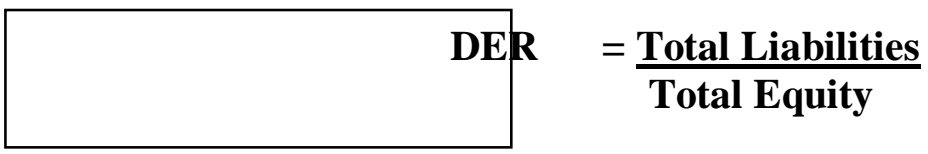

Semakin tinggi nilai rasio DER maka akan menyebabkan meningkatnya nilai hutang yang akan menyebabkan penurunan laba bersih yang pada akhirnya akan mengurangi laba yang diterima oleh pemegang saham (Sartono, 2001).

\subsection{Rasio Aktivitas}

Salah satu tujuan manajer keuangan adalah menentukan seberapa besar efisiensi investasi pada berbagai aktiva. Dengan kata lain rasio aktivitas menunjukkan bagaimana suatu sumber daya sudah dimanfaatkan secara optimal, kemudian dengan membandingkan rasio aktivitas dengan standar industri maka akan diketahui efisiensi perusahaan (Sartono, 2001). Terdapat beberapa jenis rasio aktivitas, diantaranya yaitu:

1. Perputaran Persediaan (Inventory Turnover),

2. Periode Pengumpulan Piutang (Average Collection Period),

3. Perputaran Aktiva Tetap (Fixed Asset Turnover), Dan

4. Perputaran Total Aktiva (Total Asset Turnover). 


\section{Total Asset Turnover (TATO)}

Perputaran total aktiva menunjukan bagaimana efektifitas perusahaan dalam menggunakan keseluruhan aktiva untuk menciptakan penjualan dalam kaitannya untuk mendapatkan laba. Perusahaan dengan tingkat penjualan yang besar diharapkan mendapatkan laba yang besar pula. Nilai TATO yang semakin besar menunjukan nilai penjualannya juga semakin besar pula. Total Assets Turnover secara matematis dirumuskan sebagai berikut.

\section{TATO $=$ Total Sales}

\section{Total Assets}

TATO dipengaruhi oleh nilai penjualan bersih yang dilakukan oleh perusahaan dibandingkan dengan nilai aktiva total yang dimiliki oleh perusahaan. Bila nilai TATO ditingkatkan berarti terjadi kenaikan penjualan bersih perusahaan, peningkatan penjualan bersih perusahaan akan mendorong peningkatan laba yang akan direspon dengan peningkatan harga saham perusahaan yang pada akhirnya akan meningkatkan return saham perusahaan (Sartono, 2001).

\subsection{Risiko Investasi}

Joel G. Siegel dan Jae K. Shim yang dikutip oleh Irham Fahmi (2011:2) mendefinisikan risiko dalam 3 (tiga) hal sebagai berikut:

1. Risiko adalah keadaan yang mengarah kepada sekumpulan hasil khusus, dimana hasilnya dapat diperoleh dengan kemungkinan yang telah diketahui oleh pengambil keputusan.

2. Risiko adalah variasi dalam keuntungan, penjualan, atau variabel keuntungan lainnya.

3. Risiko adalah kemungkinan dari sebuah masalah keuangan yang mempengaruhi kinerja operasi perusahaan atau posisi keuangan, seperti risiko ekonomi, ketidakpastian politik, dan masalah industri.

Setiap asset yang memiliki peluang kerugian lebih besar lebih berisiko daripada yang memiliki peluang kerugian yang lebih kecil. Semakin pasti tingkat return dari suatu asset, maka semakin kecil variabilitas dan risikonya. Risiko sering dihubungkan dengan penyimpangan atau deviasi dari outcome yang diterima dengan yang diharapkan. Oleh karena itu, dimensi risiko ada dua, yaitu menyimpang lebih kecil atau menyimpang lebih besar. Menurut Fakhruddin dan Hadianto (2001:26), risiko merupakan variabilitas return terhadap return yang diharapkan. Risiko diwujudkan dalam bentuk standar deviasi yang mengukur absolut penyimpangan nilai-nilai yang sudah terjadi dengan nilai rata-ratanya sebagai nilai yang diharapkan. Adapun perhitungan atas risiko menurut Jogiyanto (2009:221) dapat dirumuskan sebagai berikut.

$$
s=\sqrt{\frac{\sum_{i=1}^{n}\left(x_{i}-\bar{x}\right)^{2}}{n-1}}
$$

\section{Dimana :}

$\mathrm{s} \quad=$ Standar Deviasi

xi $\quad=$ Nilai return ke-1 yang mungkin terjadi

$\mathrm{E}(\mathrm{xi})=$ Nilai return yang diharapkan dari suatu sekuritas

$\mathrm{n} \quad=$ Jumlah dari observasi data historis

\subsection{Return Saham}

Menurut Mamduh M. Hanafi (2010:489) mendefinisikan return saham merupakan selisih antara harga jual saham plus aliran kas lain yang masuk (misalnya deviden) dengan harga pembelian saham tersebut. 
Return merupakan hasil yang diperoleh dari investasi yang berupa return realisasi (realized return) dan return ekspektasi (expected return). Return realisasi merupakan return yang telah terjadi yang dihitung berdasarkan data historis dan dipergunakan sebagai salah satu pengukur kinerja perusahaan. Return realisasi ini juga berguna sebagai dasar penentuan return ekspektasi (expected return) dan risiko dimasa mendatang. Return ekspektasi merupakan return yang diharapkan akan diperoleh investor dimasa mendatang yang dihitung dengan mengalikan masing-masing hasil masa depan (outcome) dengan probabilitas kejadiannya dan menjumlahkannya (Jogiyanto H.M, 2009:109).

Dalam penelitian ini konsep return yang digunakan adalah return realisasi (actual return) yang merupakan selisih antara harga saham periode sekarang dengan harga saham periode sebelumnya. Dari konsep tersebut maka perhitungan actual return menurut Jogiyanto (2009:110) dapat dirumuskan sebagai berikut.

$$
R t=\left(\frac{P_{t}-P_{t-1}}{P_{t-1}}\right)
$$

Dimana:

Rt : Actual Return

$\mathrm{P}_{\mathrm{t}}$ : Harga saham individual pada periode $t$

$\mathrm{P}_{\mathrm{t}-1:}$ Harga (indeks) saham individual pada periode sebelumnya $(\mathrm{t}-1)$.

\subsection{Penelitian Terdahulu}

Penelitian mengenai rasio keuangan perusahaan untuk mengetahui pengaruhnya terhadap return saham yang akan diperoleh investor/ pemegang sahan telah banyak dilakukan. Atika Fatmawati (2013) melakukan penelitian mengenai "Pengaruh Rasio Aktivitas, Rasio Profitabilitas, dan Rasio Pasar Terhadap Return Saham pada Perusahaan Grosir dan Ritel Periode Tahun 2008-2011”. Hasil penelitian menunjukkan bahwa terdapat pengaruh positif signifikan untuk variabel ROE dan PBV terhadap return saham, sedangkan variabel TATO, ITO, ROA, EPS tidak berpengaruh terhadap return saham.

Alfredo Mahendra DJ (2011), dalam penelitiannya mengenai "Pengaruh Kinerja Keuangan Terhadap Nilai Perusahaan (Kebijakan Dividen Sebagai Variabel Moderating) pada Perusahaan Manufaktur di BEI". Hasil penelitian menunjukkan bahwa hanya variabel rasio profitabilitas yang berpengaruh signifikan terhadap nilai perusahaan, sedangkan rasio leverage dan likuiditas berpengaruh tidak signifikan.

Andre Hernendiastoro (2005), melakukan penelitian mengenai "Pengaruh Kinerja Perusahaan dan Kondisi Ekonomi Terhadap Return Saham dengan Metode Intervalling pada Perusahaan LQ 45". Dengan hasil penelitian yang menunjukkan bahwa tidak terdapat pengaruh yang signifikan antara variabel CR, DER, ROA, PER, Inflasi, dan Kurs terhadap Return saham.

Su dan nardy (2012), melakukan penelitian mengenai "The Influence of Financial Performance on Stock Return in Basic and Chemical Industry in Indonesia". Hasil penelitian menunjukkan bahwa terdapat pengaruh positif yang signifikan antara ROA, ROE terhadap Return saham, sementara EPS menunjukan pengaruh negatif terhadap Return Saham.

Uraian dari penelitian terdahulu diatas menyimpulkan bahwa return saham menjadi bagian paling penting dalam kegiatan investasi. Para investor yang yang telah mengambil keputusan untuk melakukan investasi pada suatu perusahaan pasti memikirkan dengan matang tingkat pengembalian (return) yang akan mereka peroleh. Dan menjadi tujuan dilakukannya penelitian ini, yaitu mengetahui pengaruh antara rasio profitabilitas, solvabilitas, aktivitas, serta risiko investasi terhadap return saham. 


\subsection{Hipotesis Penelitian}

Berdasarkan penjabaran diatas, maka dapat dikumpulkan keseluruhan hipotesis yang akan diuji dalam penelitian ini, yaitu sebagai berikut:

1. Rasio profitabilitas, solvabilitas, aktivitas, dan risiko investasi secara bersama-sama mempunyai pengaruh terhadap return saham.

2. Rasio profitabilitas, solvabilitas, aktivitas, dan risiko investasi secara parsial mempunyai pengaruh terhadap return saham.

a. Net Profit Margin (NPM) berpengaruh secara positif terhadap return saham.

b. Debt to Equity Ratio (DER) berpengaruh negatif terhadap return saham.

c. Total Assets Turnover (TATO) berpengaruh positif terhadap return saham.

d. Risiko Investasi berpengaruh positif terhadap return saham.

\section{METODE PENELITIAN}

\subsection{Operasional Variabel}

Metode penelitian yang digunakan dalam penelitian ini adalah metode deskriptif dan verifikatif. Metode ini dipilih karena terdapat variabel-variabel yang akan ditelaah hubungannya dan tujuannya untuk menyajikan gambaran secara terstruktur, faktual, dan akurat mengenai fakta-fakta serta hubungan antar variabel yang diteliti. Adapun instrumen penelitian yang digunakan dalam penelitian ini adalah sebagai berikut :

1. Variabel X (variabel independen)

Variabel independen adalah variabel yang mempengaruhi atau yang menjadi sebab perubahannya atau timbulnya variabel dependen. Yang termasuk variabel independen adalah sebagai berikut:

1) Rasio Profitabilitas : Net Profit Margin $\left(\mathrm{X}_{1}\right)$

2) Rasio Solvabilitas : Debt Equity Ratio $\left(\mathrm{X}_{2}\right)$

3) Rasio Aktivitas: Total Assets Turnover $\left(\mathrm{X}_{3}\right)$

4) Risiko Investasi $\left(X_{4}\right)$

2. Variabel Y (variabel dependen)

Variabel dependen merupakan variabel yang dipengaruhi atau yang menjadi akibat, karena adanya variabel bebas. Return Saham, sebagai variabel dependen (Y).

\subsection{Penentuan Populasi dan Sampel}

Penelitian ini menggunakan data sekunder yang meliputi data-data pada laporan keuangan dari perusahaan otomotif yang dipublikasikan setiap perusahaan yang terdaftar di Bursa Efek Indonesia tahun 2011-2015. Terdapat 13 populasi perusahaan otomotif yang terdaftar di BEI, namun hanya 12 perusahaan otomotif yang secara rutin melaporkan laporan keuangannya selama periode tahun 2011-2015, dan 12 perusahaan ini akan dijadikan sampel dalam penelitian ini. Sehingga penentuan jumlah data menggunakan populasi tersebut yaitu saham perusahaan otomotif tahunan selama periode 2011-2015 sejumlah 60 data.

\subsection{Rancangan Analisis dan Uji Hipotesis}

Dalam penelitian ini, pengolahan data dilakukan dengan menggunakan program SPSS 16.0 for windows. Data sekunder yang telah terkumpul, kemudian diolah dengan menggunakan analisis deskriptif, uji asumsi klasik, uji normalitas, uji koefisien determinasi dan selanjutnya dilakuka pengujian hipotesis.

\subsubsection{Regresi Berganda}

Analisis data untuk mengetahui ada atau tidaknya pengaruh variabel bebas terhadap variabel terikat menggunakan metode analisa regresi berganda dengan pengolahan data 
menggunakan program SPSS. Adapun persamaan dari analisis regresi ni menurut Sugiyono (2012:257) adalah sebagai berikut:

\begin{tabular}{ll}
\hline Regresi Sederhana & $: Y=\alpha+\beta X$ \\
Regresi Berganda & $: Y=\alpha+\beta_{1} X_{1}+\beta_{2} X_{2}+\beta_{3} X_{3}+\beta_{4} X_{4}+e$
\end{tabular}

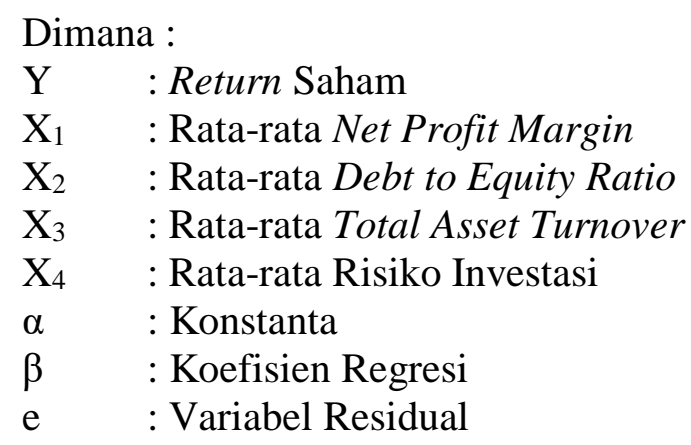

Besarnya konstanta dalam $\alpha$, dan besarnya koefisien dari masing-masing variabel independen ditunjukkan dengan $\beta_{1}, \beta_{2}, \beta_{3}$, dan $\beta_{4}$, keempat variabel bebas tersebut merupakan faktor fundamental perusahaan, sedangkan variabel dependennya adalah return saham.

\subsubsection{Koefisien Determinasi $\left(\mathbf{R}^{2}\right)$}

Analisis determinasi digunakan untuk menjelaskan seberapa besar pengaruh variabel independen $(\mathrm{X})$ terhadap variabel dependen $(\mathrm{Y})$ yang merupakan hasil pangkat dua dari koefisien korelasi. Menurut Sugiyono (2012:292), rumus untuk menghitung koefisien determinasi yaitu:

$$
K_{d}=R^{2} \times 100 \%
$$

Dimana : $0 \leq \mathrm{r}^{2} \leq 1$

Keterangan :

$\mathrm{K}_{\mathrm{d}}=$ Koefisien determinasi

$\mathrm{R}^{2}=$ Koefisien korelasi

\subsubsection{Uji Hipotesis}

Pengujian hipotesis dilakukan dengan menggunakan metode two tailed test. Untuk menguji hipotesis yang telah diajukan, maka uji yang digunakan adalah:

1. Uji F (Uji Simultan)

Uji $F$ digunakan untuk melihat pengaruh variabel independen secara keseluruhan/bersama-sama terhadap variabel dependen. Jadi uji F dalam penelitian ini digunakan untuk mengetahui pengaruh profitabilitas (NPM), solvabilitas (DER), aktifitas (TATO), dan risiko investasi (standar deviasi) secara bersama-sama terhadap return saham.

2. Uji T (Uji Parsial)

Uji t digunakan untuk melihat signifikansi antara koefisien regresi individual, yaitu melihat pengaruh variabel independen terhadap variabel dependen secara parsial. Jadi uji t dalam penelitiian ini digunakan untuk mengetahui pengaruh profitabilitas (NPM), solvabilitas (DER), aktifitas (TATO), dan risiko investasi (standar deviasi) secara parsial terhadap return saham. 


\section{HASIL DAN PEMBAHASAN}

\subsection{Uji Asumsi Klasik}

Berdasarkan hasil pengujian asumsi Klasik dapat disimpulkan bahwa analisis regresi sederhana dan berganda dari variabel independen net profit margin $\left(\mathrm{X}_{1}\right)$, debt to equity ratio $\left(\mathrm{X}_{2}\right)$, total asset turnover $\left(\mathrm{X}_{3}\right)$, dan risiko investasi $\left(\mathrm{X}_{4}\right)$ terhadap variabel dependen return saham (Y) memenuhi syarat korelasi, karena :

1. Uji Normalitas Data, titik-titik menyebar data berada di sekitar garis diagonal, dan penyebarannya menjauhi arah garis diagonal. Sehingga, model regresi ini menyalahi asumsi normalitas.

2. Uji Multikolinieritas, model regresi tersebut tidak terdapat problem multikolinieritas baik berdasarkan pada besaran VIF maupun besaran korelasi antar variabel.

3. Uji Autokorelasi, model regresi ini menyimpulkan bahwa terdapat masalah autokorelasi.

4. Uji Heterokedisitas, pada model regresi tersebut tidak terjadi heteroskedisitas, maka model regresi layak digunakan untuk prediksi regresi.

\subsection{Analisis Regresi Linear Berganda}

Analisis dalam penelitian ini digunakan untuk menganalisis pengaruh net profit margin, debt to equity ratio, total asset turnover, dan risiko investasi secara regresi berganda terhadap return saham pada perusahaan sektor otomotif dan komponen yang tergabung di BEI Tahun 2011-2015. Berikut tabel analisis regresi berganda disajikan dalam tabel berikut.

\section{Analisis Regresi Berganda}

\section{NPM, DER, TATO, dan Risiko Investasi terhadap Return Saham}

\section{Coefficients $^{\mathrm{a}}$}

\begin{tabular}{|c|c|c|c|c|c|}
\hline \multirow[b]{2}{*}{ Model } & \multicolumn{2}{|c|}{$\begin{array}{l}\text { Unstandardi } \\
\quad \text { zed } \\
\text { Coefficients }\end{array}$} & \multirow{2}{*}{$\begin{array}{c}\begin{array}{c}\text { Standardiz } \\
\text { ed } \\
\text { Coefficien } \\
\text { ts }\end{array} \\
\\
\text { Beta }\end{array}$} & \multirow[b]{2}{*}{$\mathrm{t}$} & \multirow[b]{2}{*}{ Sig. } \\
\hline & B & $\begin{array}{l}\text { Std. } \\
\text { Error }\end{array}$ & & & \\
\hline $\begin{array}{l}\text { 1(Consta } \\
\text { nt) }\end{array}$ & -.204 & .156 & & $\begin{array}{r}1.30 \\
9\end{array}$ & .196 \\
\hline NPM & .033 & .010 & .368 & $\begin{array}{r}3.49 \\
1\end{array}$ & .001 \\
\hline DER & -.089 & .080 & -.116 & $\begin{array}{r}1.11 \\
4\end{array}$ & .270 \\
\hline TATO & .052 & .131 & .043 & .398 & .692 \\
\hline $\begin{array}{l}\text { RISIK } \\
\text { O_INV } \\
\text { ESTAS } \\
\text { I }\end{array}$ & $\begin{array}{r}1.82 \\
3\end{array}$ & .310 & .615 & $\begin{array}{r}5.87 \\
7\end{array}$ & .000 \\
\hline
\end{tabular}




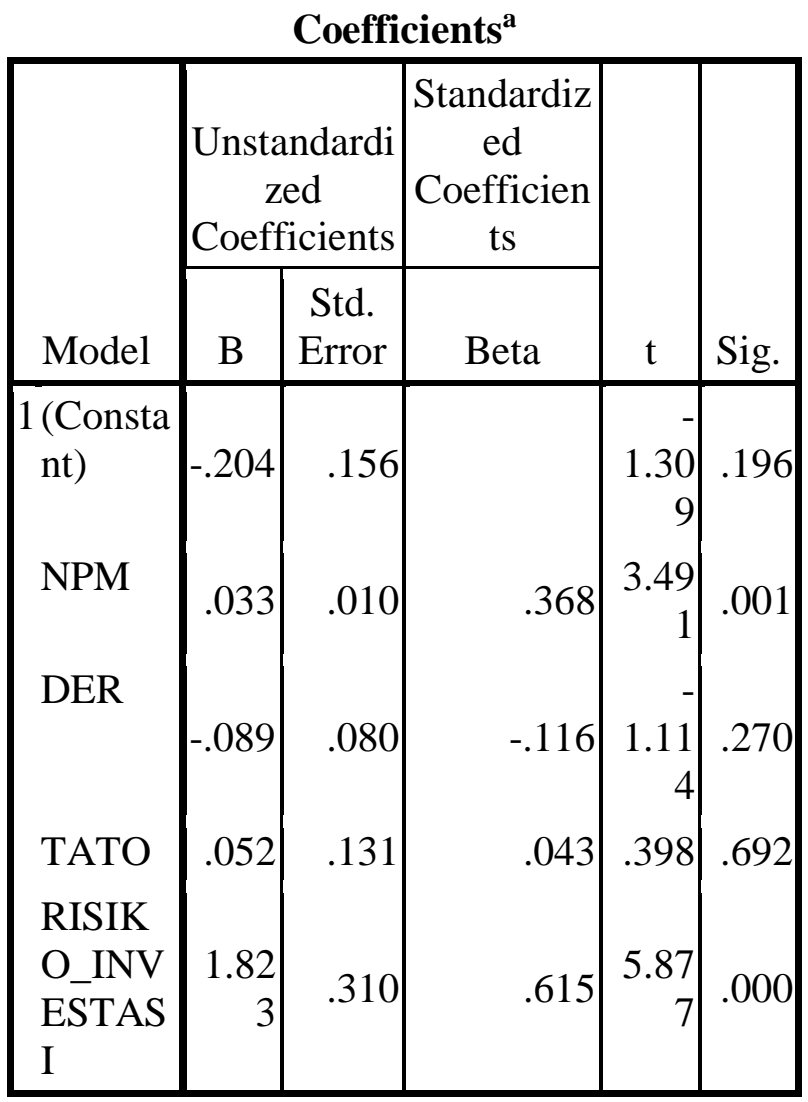

a. Dependent

Variable:

RETURN_SAHAM

Berdasarkan tabel diatas, diperoleh persamaan regresi linear berganda sebagai berikut: $\mathrm{Y}=\mathrm{a}+\beta_{1} \mathrm{X}_{1}+\beta_{2} \mathrm{X}_{2}+\beta_{3} \mathrm{X}_{3}+\beta_{4} \mathrm{X}_{4}+\mathrm{e}$

$\hat{Y}=-0,204+0,33 X_{1}-0,089 X_{2}+0,052 X_{3}+1,823 X_{4}$

\subsection{Koefisien Determinasi} berikut:

Hasil Koefisien korelasi $\mathrm{R}$ dan koefisien determinasi $\left(\mathrm{R}^{2}\right)$ dapat dilihat pada tabel Analisis Koefisien Determinasi $\left(\mathbf{R}^{\mathbf{2}}\right)$

Model Summary

\begin{tabular}{|c|c|r|r|c|}
\hline $\begin{array}{c}\text { Mode } \\
1\end{array}$ & $\mathrm{R}$ & $\begin{array}{c}\mathrm{R} \\
\text { Square }\end{array}$ & $\begin{array}{c}\text { Adjusted } \\
\mathrm{R} \text { Square }\end{array}$ & $\begin{array}{c}\text { Std. } \\
\text { Error of } \\
\text { the } \\
\text { Estimate }\end{array}$ \\
\hline 1 & $.695^{\mathrm{a}}$ & .486 & .457 & .3737250 \\
\hline
\end{tabular}
a. Predictors: (Constant), RISIKO_INVESTASI, DER, TATO, NPM

b. Dependent Variable:

RETURN_SAHAM 

berikut :

Dari tabel diatas, dapat dilihat hasil output pengolahan data dapat dijelaskan sebagai

a. Koefisien korelasi (R) sebesar 0,695 yang menunjukkan hubungan antara variabel net profit margin, debt to equity ratio, Total Asset Turnover, dan risiko investasi terhadap return saham adalah positif 0,695. Menurut Santoso (2002) jika $\mathrm{R}>0,5$ hal ini membuktikan bahwa hubungan antara variabel net profit margin, debt to equity ratio, Total Asset Turnover, dan risiko investasi dengan return saham adalah kuat.

b. Koefisien determinasi $\left(\mathrm{R}^{2}\right)$ menggunakan adjusted $R$ square sebesar 0,457, hasil tersebut menunjukkan bahwa besarnya return saham yang dapat dijelaskan oleh variabel net profit margin, debt to equity ratio, Total Asset Turnover, dan risiko investasi adalah sebesar $45,7 \%$ dan yang dijelaskan oleh variabel lain di luar model sebesar $54,3 \%(100 \%-45,7 \%)$.

\subsection{Hasil Pengujian Hipotesis}

\subsubsection{Pengujian Pengaruh Simultan (Uji F)}

Pengujian ini dilakukan dengan menggunajak uji F (F-test). Adapun hasil uji hipotesis dengan menggunakan uji $\mathrm{F}$ adalah sebagai berikut:

\section{ANOVA $^{b}$}

\section{Uji Pengaruh Simultan (Uji F)}

\begin{tabular}{|l|c|c|c|c|c|}
\hline Model & $\begin{array}{c}\text { Sum } \\
\text { of } \\
\text { Squar } \\
\text { es }\end{array}$ & df & $\begin{array}{l}\text { Mean } \\
\text { Squar } \\
\text { e }\end{array}$ & F & Sig. \\
\hline $\begin{array}{l}1 \text { Regress } \\
\text { ion } \\
\text { Residua } \\
1\end{array}$ & 6.444 & 4 & 1.611 & 11.53 & .000 \\
Total & 7.682 & 55 & .140 & & \\
\hline
\end{tabular}

a. Predictors: (Constant), RISIKO_INVESTASI, DER, NPM, TATO

b. Dependent Variable:

RETURN_SAHAM

Sumber: Hasil Pengolahan Data

Dari hasil uji $\mathrm{F}$ di atas menunjukkan bahwa nilai $\mathrm{F}_{\text {hitung }}$ sebesar 11,535 dan $\mathrm{F}_{\text {tabel }}$ sebesar 2,54 (didapat dari $\mathrm{N}=60$; df $1=5-1=4$ dan df2 $=60-5=55$, maka NIlai $\mathrm{F}$ Tabel adalah

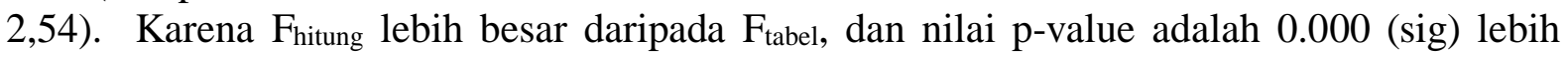
kecil dari alpha 0.05 (confidence interval), maka dapat disimpulkan bahwa koefisien regresi secara keseluruhan adalah signifikan pada tingkat 5\%, Dimana $\mathrm{H}_{\mathrm{o}}$ ditolak dan $\mathrm{H}_{1}$ diterima. Dengan demikian hal ini menunjukkan bahwa terdapat pengaruh yang signifikan secara bersama-sama antara net profit margin, debt to equity ratio, Total Asset Turnover, dan risiko investasi terhadap return saham.

\subsubsection{Pengujian Pengaruh Parsial (Uji T)}

Uji $t$ pada masing-masing variabel dikatakan berpengaruh signifikan jika nilai $t_{\text {tabel }}$ lebih kecil dari pada thitung. Untuk mendapatkan nilai $t_{\text {tabel }}$ dapat dihitung dengan 
menggunakan rumus df1 $=\mathrm{n}-\mathrm{k}=60-4=56$ dengan tingkat signifikansi 0,05. Maka dapat disimpulkan nilai $t_{\text {tabel }}$ sebesar 1.67252. Sedangkan hasil thitung disajikan dalam tabel berikut.

\section{Uji Pengaruh Parsial (Uji T)}

\begin{tabular}{|c|c|c|c|c|c|c|c|c|c|c|}
\hline \multirow{2}{*}{ Model } & \multicolumn{2}{|c|}{$\begin{array}{l}\text { Unstandardize } \\
\text { Coefficients }\end{array}$} & \multirow{2}{*}{\begin{tabular}{|c|}
$\begin{array}{c}\text { Standardized } \\
\text { Coefficients }\end{array}$ \\
Beta \\
\end{tabular}} & \multirow{2}{*}{$\mathrm{t}$} & \multirow{2}{*}{ Sig. } & \multicolumn{3}{|c|}{ Correlations } & \multicolumn{2}{|c|}{$\begin{array}{l}\text { Collinearity } \\
\text { Statistics }\end{array}$} \\
\hline & B & $\begin{array}{l}\text { Std. } \\
\text { Error }\end{array}$ & & & & $\begin{array}{l}\text { Zero- } \\
\text { order }\end{array}$ & Partial & Part & Tolerance & VIF \\
\hline 1 (Constant) & -.204 & .156 & & -1.309 & .196 & & & & & \\
\hline NPM & .033 & .010 & .368 & 3.491 & .001 & -.249 & -426 & $-347 \mid$ & 890 & 1.123 \\
\hline DER & -.089 & .080 & -.116 & -1.114 & .270 & -.221 & $\mid-149$ & -111 & .916 & 1.092 \\
\hline TATO & .052 & .131 & .043 & .398 & .692 & -011 & .054 & .040 & 852 & 1.173 \\
\hline $\begin{array}{l}\text { RISIKO_INV } \\
\text { ESTASI }\end{array}$ & 1.823 & .310 & .615 & 5.877 & .000 & 552 & .621 & 584 & .904 & 1.107 \\
\hline
\end{tabular}

Sumber: Hasil Pengolahan Data

Berdasarkan data pada tabel diatas dapat diambil kesimpulan sebagai berikut:

1. Variabel Net Profit Margin (NPM) memiliki pengaruh yang signifikan terhadap Return Saham.

2. Variabel Debt to Equity Ratio (DER) tidak memiliki pengaruh signifikan terhadap Return Saham.

3. Variabel Total Asset Turnover (TATO) tidak memiliki pengaruh signifikan terhadap Return Saham.

4. Variabel Risiko Investasi memiliki pengaruh signifikan terhadap Return Saham.

\subsection{Pembahasan Hasil Penelitian}

Berdasarkan hasil penelitian dan uraian di atas berikut pembahasan atas hasil pengujian

1. Net profit margin, debt to equity ratio, Total Asset Turnover, dan risiko investasi secara parsial terhadap Return saham pada perusahaan otomotif dan komponen yang tergabung di BEI tahun 2011-2015.

a. Net profit margin

Berdasarkan hasil pengujian secara parsial, diperoleh bahwa Net Profit Margin (NPM) berpengaruh dan signifikan terhadap Return Saham. Hal ini terlihat dari nilai $\mathrm{t}$ hitung $(3,491)$ lebih besar dari nilai t tabel (1.67252) dengan tingkat signifikansi 0,001 yang lebih kecil dari pada 0,05 .

Dengan demikian, hasil penelitian ini mendukung penelitian yang dilakukan oleh Hesty Heriati (2011), yang menyatakan bahwa NPM berpengaruh signifikan terhadap return saham.

b. Debt to equity ratio

Berdasarkan hasil pengujian secara parsial, diperoleh bahwa Debt to equity ratio (DER) tidak berpengaruh dan tidak signifikan terhadap Return Saham. Hal ini terlihat dari nilai $t$ hitung $(-1,114)$ lebih kecil dari nilai t tabel $(1.67252)$ dengan tingkat signifikansi 0,270 yang lebih besar dari pada 0,05 .

Dengan demikian, hasil penelitian ini tidak mendukung penelitian yang dilakukan oleh Astohar (2010), yang menyatakan hasil penelitian bahwa DER memiliki pengaruh negatif signifikan terhadap return saham.

c. Total Asset Turnover

Berdasarkan hasil pengujian secara parsial, diperoleh bahwa Total Asset Turnover (TATO) tidak berpengaruh dan tidak signifikan terhadap Return Saham. Hal ini terlihat dari nilai $\mathrm{t}$ hitung $(0,398)$ lebih kecil dari nilai t tabel (1.67252) dengan tingkat signifikansi 0,692 yang lebih besar dari pada 0,05. 
Dengan demikian, hasil penelitian ini tidak mendukung penelitian yang dilakukan oleh Kennedy (2003), yang menyatakan hasil penelitian bahwa TATO memiliki pengaruh positif signifikan terhadap return saham.

d. Risiko investasi

Berdasarkan hasil pengujian secara parsial, diperoleh bahwa risiko investasi berpengaruh signifikan terhadap Return Saham. Hal ini terlihat dari nilai t hitung $(5,877)$ lebih besar dari nilai t tabel (1.67252) dengan tingkat signifikansi 0,00 yang lebih kecil dari pada 0,05 .

Dengan demikian, hasil penelitian ini mendukung penelitian yang dilakukan oleh Hesty Heriati (2011) menunjukan bahwa faktor Risiko berpengaruh terhadap return saham.

2. Net profit margin, debt to equity ratio, Total Asset Turnover, dan risiko investasi secara simultan terhadap Return saham pada perusahaan otomotif dan komponen yang tergabung di BEI tahun 2011-2015.

a. Berdasarkan hasil uji $\mathrm{F}$ di atas menunjukkan bahwa $\mathrm{H}_{\mathrm{o}}$ ditolak dan $\mathrm{H}_{1}$ diterima. Dengan demikian hal ini menunjukkan bahwa terdapat pengaruh yang signifikan secara bersama-sama antara net profit margin, debt to equity ratio, Total Asset Turnover, dan risiko investasi terhadap return saham.

b. Hasil dari pengujian koefisien korelasi (R) sebesar 0,695 juga menunjukkan adanya hubungan yang kuat antara variabel net profit margin, debt to equity ratio, Total Asset Turnover, dan risiko investasi terhadap return saham yaitu sebesar 0,695.

c. Berdasarkan uji koefisien determinasi $\left(\mathrm{R}^{2}\right)$ menggunakan adjusted $R$ square sebesar 0,457 , hasil tersebut menunjukkan bahwa besarnya return saham yang dapat dijelaskan oleh variabel net profit margin, debt to equity ratio, Total Asset Turnover, dan risiko investasi adalah sebesar $45,7 \%$ dan yang dijelaskan oleh variabel lain di luar model sebesar 54,3\%. Dengan demikian net profit margin, debt to equity ratio, Total Asset Turnover, dan risiko investasi apabila dilakukan secara bersama-sama, dapat meningkatkan return saham sebesar 45,7\%.

\section{SIMPULAN DAN SARAN}

\subsection{Simpulan}

Berdasarkan hasil penelitian dan pembahasan yang telah dilakukan pada bab-bab sebeumnya , maka dapat disimpulkan sebagai berikut:

1. Posisi profitabilitas yang diwakili oleh net profit margin (NPM) pada perusahaan otomotif dan komponen mengalami penurunan. Secara parsial hubungan profitabilitas dengan return saham berpengaruh dan signifikan.

2. Posisi solvabilitas yang diwakili oleh debt to equity ratio (DER) tidak berpengaruh dan tidak signifikan terhadap return saham. Hal ini menunjukkan bahwa kemampuan perusahaan dalam memenuhi hutang jangka panjangnya masih belum maksimal.

3. Posisi rasio aktivitas yang diwakili oleh total asset turnover (TATO) tidak berpengaruh dan tidak signifikan terhadap return saham, hal ini menunjukkan bahwa perusahaan sektor otomotif dan komponen memiliki kemampuan yang cukup efektif dalam mengelola aktivanya.

4. Posisi risiko investasi pada perusahaan otomotif dan komponen berpengaruh dan tidak signifikan terhadap return saham, hal ini menunjukan bahwa tingkat risiko investasi dalam sektor otomotif dan komponen memiliki tingkat return yang tidak terlalu tinggi.

5. Kondisi return saham pada perusahaan otomotif dan komponen tidak stabil, hal ini menunjukkan bahwa perusahaan sektor otomotif dan komponen rata-rata memiliki kemampuan return saham yang rendah, yang berarti belum maksimalnya kemampuan operasi perusahaan. 
6. Berdasarkan hasil pengujian secara simultan diperoleh hasil dimana $F_{\text {hitung }}$ lebih besar daripada $\mathrm{F}_{\text {tabel, }}$ yang artinya $\mathrm{H}_{\mathrm{o}}$ ditolak dan $\mathrm{H}_{1}$ diterima. Dengan demikian hal ini menunjukkan bahwa terdapat pengaruh yang signifikan secara bersama-sama antara net profit margin, debt to equity ratio, Total Asset Turnover, dan risiko investasi terhadap return saham.

\subsection{Saran}

Adapun saran-saran yang dapat dipertimbangkan sehubungan dengan hasil penelitian adalah sebagai berikut :

1. Perlu adanya peningkatan penjualan pada sektor otomotif dan komponen, sehingga akan berpengaruh terhadap kemampuan perusahaan dalam menghasilkan laba perusahaan. Dan hal ini akan berdampak pada posisi Profitabilitas akan juga akan mengalami kenaikan.

2. Perlu mengoptimalkan posisi solvabilitas atau struktur modal perusahaan otomotif dan komponen, yaitu dengan lebih mengefisienkan dan mengefektifkan penggunaan modal perusahaan, serta mengendalikan biaya-biaya yang dikeluarkan sehingga kewajibankewajiban perusahaan pun dapat terkendali dengan baik.

3. Perlu peningkatan untuk posisi Aktivitas perusahaan, yaitu dengan mengoptimalkan penggunaan aset perusahaan dalam aktivitas penjualan, sehingga dapat meningkatkan laba perusahaan.

4. Tingginya tingkat risiko investasi menyebabkan perusahaan sektor otomotif dan komponen harus lebih memaksimalkan aktivitas pengendaliannya, sehingga risiko investasi ini tidak akan memberikan pengaruh buruk untuk return investasinya.

5. Perlu adanya peningkatan dalam Return saham pada sektor otomotif dan komponen, salah satunya dengan cara meningkatkan laba perusahaan. Hal ini akan berpengaruh pada harga saham perusahaan, sehingga dapat menaikan tingkat return sahamnya.

\section{DAFTAR PUSTAKA}

Fakhruddin, Firmansyah dan Hadianto. 2001. Manajemen Investasi Portofolio. Jakarta: Salemba Empat.

Hanafi, Mamduh M. 2010. Manajemen Keuangan: Teori dan Aplikasi. Yogyakarta: BPFE UGM.

Harahap, Sofyan Syafri. 2008. Analisis Kritis atas Laporan Keuangan. Jakarta: PT. Raja Grafindo Persada.

Jogiyanto, Hartono. 2009. Teori Portofolio dan Analisis Investasi. Edisi Keenam. Yogyakarta: BPFE.

Munawir, S. 2007. Analisis Laporan Keuangan. Yogyakarta: Liberty.

Sartono, agus. 2001. Manajemen Keuangan dan Aplikasi, Edisi 2. Yoyakarta: BPFE UGM.

Sawir, Agnes . 2005. Analisis Kinerja Keuangan dan Perencanaan Keuangan Perusahaan. Jakarta : PT. Gramedia Pustaka Utama.

Siegel, Joel., dan Jae K Shim. 2011. Amus Istilah Akuntansi. Jakarta: PT. Elex Media Komputindo.

Sugiyono. 2012. Metode Penelitian Bisnis. Bandung: Alfabeta. 